\title{
Optimalisasi peran internet dalam mewujudkan digital citizenship dan implikasinya terhadap ketahanan pribadi siswa
}

\author{
Armaidy Armawi ${ }^{\text {a }}$, Darto Wahidin ${ }^{\mathrm{b}}$ \\ a Fakultas Filsafat, Universitas Gadjah Mada, Yogyakarta, Indonesia \\ b Program Studi Ketahanan Nasional, Universitas Gadjah Mada, Yogyakarta, Indonesia
}

\section{ABSTRAK}

Sejarah Artikel

Individu usia sekolah merupakan salah satu pengakses internet dengan menggunakan media sosial paling aktif. Akses internet menjadi sangat yang rawan, mengingat penggunaannya di dominasi oleh kalangan usia sekolah. Beredarnya isu hoax, fitnah, bahkan menghujat melalui media sosial yang dengan mudahnya di akses melalui internet, menunjukkan belum dewasanya dalam penggunaan internet. Tujuan dalam penelitian ini mengetahui proses optimalisasi peran internet dalam mewujudkan digital citizenship di Kota Semarang dan mengkaji implikasi dari optimalisasi peran internet terhadap ketahanan pribadi siswa di Kota Semarang. Penelitian ini menggunakan pendekatan kualitatif. Temuan penelitian menunjukkan bahwa proses optimalisasi peran internet dalam mewujudkan digital citizenship di SMA Negeri 1 Semarang dan SMK Negeri 1 Semarang dilakukan dengan mengoptimalkan akses digital, digital literacy, dan perdagangan digital. Implikasi dari optimalisasi peran internet terhadap ketahanan pribadi siswa dengan adanya hukum digital dan mewujudkan digital citizenship. Sembilan kriteria dalam mewujudkan digital citizenship telah terpenuhi, namun masih harus ada perbaikan untuk mengoptimalkannya.

Diterima: 12 Februari 2020

Disetujui: 16 April 2020

\section{Kata kunci:}

Kewarganegaraan digital, ketahanan siswa, internet

\section{Keywords:}

Digital citizenship, student resilience, internet

\section{ABSTRACT}

School-age is the most active social media. Internet access is very vulnerable, considering that school-age groups dominate its use. Circulation of hoax, slander, and even blasphemy through social media easily accessed via the internet shows not yet mature in using the internet. The purpose of this study is to determine the process of optimizing the role of the internet in realizing digital citizenship in Semarang City and examining the implications of optimizing the role of the internet for the personal endurance of students in the city of Semarang. This research uses a qualitative approach. The research findings that the process of optimizing the role of the internet in realizing digital citizenship in SMA (Senior High Scholl) Negeri 1 Semarang and SMK (Vocational High School) Negeri 1 Semarang carried out by optimizing digital access, digital literacy, and digital commerce. Implications of optimizing the role of the internet on students' personal resilience in the presence of digital laws and realizing digital citizenship. Nine criteria in realizing digital citizenship have met, but there must still be improvements to optimize it.

\section{Pendahuluan}

Teknologi pada dasarnya diciptakan untuk proses mempermudah pekerjaan manusia dan untuk memenuhi segala kebutuhan hidup manusia itu sendiri. Adanya teknologi, informasi, dan komunikasi yang sangat berkembang pesat, telah mengubah kehidupan manusia. Persyaratan utama bagi seseorang yang menggunakan teknologi, informasi, dan komunikasi secara efektif tidak hanya untuk hiburan tetapi, juga mencari dan berbagai informasi. Sebagaimana yang dijanjikan dari teknologi yaitu, 1) teknologi menjanjikan perubahan; 2) teknologi menjanjikan kemajuan; 3) teknologi menjanjikan kemudahan; 4) teknologi menjanjikan peningkatan produktivitas, dan 5) teknologi menjanjikan ketepatan serta kecepatan (Martono, 2014).

Salah satu bentuk penunjang dalam menjalankan teknologi yakni dengan menggunakan internet. Survei global baru-baru ini telah mengidentifikasi lebih dari $75 \%$ pengguna internet 
berinteraksi dengan media sosial (Poushter et al., 2018; Xu et al., 2019). Media sosial seperti Facebook, Twitter, Line, WhatsApp, Instagram, dan Blackberry Messenger telah mengubah cara berinteraksi kehidupan manusia. Tingkat adopsi media sosial yang tertinggi terjadi di negaranegara berkembang (Poushter et al., 2018). Indonesia yang merupakan negara berkembang, dengan tingkat penduduknya yang menempati urutan keempat di dunia setelah China, India, dan Amerika Serikat. Sebagaimana laporan Tetra Pak Index tahun 2017, sekitar 132 juta pengguna internet di Indonesia, 40\% nya penggila media sosial (Yudhianto, 2017)

Sekolah sebagai sebuah dunia pendidikan dan lembaga formal, tentunya sangat penting memandang internet ini. Namun, terkadang kebutuhan akan internet di sekolah tersebut belum memadai dan belum terjangkau dengan baik untuk kalangan sekolah itu sendiri. Padahal akses informasi, komunikasi, dan pengetahuan dapat mudah dijangkau dengan adanya internet. Masalah pembiayaan dan alokasi anggaran yang disediakan sekolah setiap tahunnya yang tidak terlalu besar. Banyak sekolah yang memakai internet, namun hanya pada wilayah tertentu atau koridor tertentu saja, misalnya saja hanya untuk ruang guru atau ruang tata usaha. Ditambah lagi dengan jumlah siswa siswi yang besar di sekolah tersebut, yang semuanya ingin menikmati akses internet yang telah disediakan oleh sekolah. Maka banyak sekolah yang bekerja sama dengan kalangan provider kartu perdana maupun penyedia akses internet demi untuk mendukung penggunaan internet yang memadai untuk warga sekolahnya.

Individu usia sekolah merupakan salah satu pengakses internet dengan menggunakan media sosial paling aktif. Penelitian menunjukkan $86 \%$ orang yang berusia antara 18 hingga 19 tahun menggunakan setidaknya satu bentuk media sosial (Smith, 2017). Hal ini menunjukkan bahwa akses internet menjadi sangat yang rawan, mengingat penggunaannya di dominasi oleh kalangan usia sekolah, yang secara usia belum matang dalam proses memilah dan memilih informasi yang beredar. Keaktifan kalangan usia sekolah dalam menggunakan akses internet tentunya harus diimbangi pula dengan pengawasan yang ketat sehingga dapat memilah dan memilih informasi yang benar dan baik.

Mudahnya menerima informasi tanpa memilah dan memilih terlebih dahulu apakah informasi tersebut benar atau salah yang dilakukan oleh kalangan usia sekolah dapat menyebabkan dampak yang positif maupun negatif terhadap dirinya sendiri maupun orang lain. Bagi orang lain dengan tersebarnya informasi yang positif melalui media sosial dapat menambah wawasan sekaligus pengetahuan, namun jika informasi yang buruk yang beredar di media sosial tersebut sudah dapat dipastikan sangat menjengkelkan bagi orang tersebut. Akhir-akhir ini di Indonesia dengan meluasnya arus informasi yang mudah sekali diakses melalui internet, justru informasi yang beredar melalui media sosial tersebut terkadang berisi kebencian terhadap pemimpin bahkan sampai menyebarkan berita yang palsu dan fitnah.

Beredarnya isu hoax, fitnah, bahkan saling menghujat di media sosial yang dengan mudahnya di akses melalui internet tersebut, menunjukkan belum dewasanya dalam penggunaan internet. Berita palsu seperti itu dapat memecah belah persatuan dan kesatuan bangsa Indonesia. Berita hoax dan fitnah tersebut sesungguhnya tidak sesuai dengan budaya masyarakat Indonesia dan nilai-nilai yang terkandung dalam Pancasila. Berita palsu yang beredar terkadang dibuat oleh oknum tertentu dengan tujuan yang sangat beragam, ada yang ingin cari sensasi sampai tidak memahami bahwa penggunaan internet dalam hitungan detik dapat dilihat oleh ribuan orang yang mengakses internet. Beredarnya berita hoax dan fitnah yang ada saat ini terkadang dijadikan politisasi bahkan dijadikan penggorengan oleh aktor-aktor politik terhadap pemimpin yang tidak disukainya. Internet adalah teknologi yang netral, bebas, terbuka dan tidak diatur, dan membuat semua terhubung, tetapi tidak ada yang bertanggung jawab, atau dengan kata lain dianalogikan 
bahwa internet adalah demokrasi, tetapi tanpa konstitusi (Friedman, 1999; Scobey, 2001). Proses seperti ini yang terkadang ditiru oleh kalangan usia sekolah, yang jelas-jelas hal tersebut sangat buruk. Maka diperlukan optimalisasi penggunaan terhadap internet itu sendiri oleh semua kalangan, agar dapat mewujudkan digital citizenship.

Melihat permasalahan di atas tersebut, sesungguhnya penelitian ini dipandang sangat penting untuk memecahkan permasalahan terkait dengan digital citizenship. Berdasarkan latar belakang yang telah dikemukakan di atas dapat dirumuskan permasalahan sebagai berikut: 1) bagaimana proses optimalisasi peran internet dalam mewujudkan digital citizenship di Kota Semarang?; dan 2) bagaimana implikasi dari optimalisasi peran internet terhadap ketahanan pribadi siswa di Kota Semarang?. Maka penelitian ini mempunyai tujuan untuk mengetahui proses optimalisasi peran internet dalam mewujudkan digital citizenship di Kota Semarang dan mengkaji implikasi dari optimalisasi peran internet terhadap ketahanan pribadi siswa di Kota Semarang.

Penelitian yang terkait dengan digital citizenship amatlah sedikit, apalagi yang mengkaji dari lembaga sekolah. Beberapa penelitian terdahulu yang mengkaji digital citizenship (Hintz et al., 2017; Richards, 2010; Wahidin, 2018). Semua penelitian terdahulu yang telah ditulis tersebut dalam bentuk deskripsi yang mengkaji masalah digital citizenship. Penelitian terdahulu hanya melihat dari segi ruang lingkup penelitian mikro. Penelitian tersebut juga hanya melibatkan guru, siswa, dan masyarakat dalam skala kecil. Oleh karena itu, penelitian ini ingin mengkaji dan mendalami pendidikan kewarganegaraan terkait permasalahan digital citizenship dari segi ruang lingkup penelitian makro, dengan judul optimalisasi peran internet dalam mewujudkan digital citizenship dan implikasinya terhadap ketahanan pribadi siswa di Kota Semarang.

Optimalisasi banyak juga diartikan sebagai ukuran di mana semua kebutuhan dapat dipenuhi dari kegiatan-kegiatan yang dilaksanakan. Optimalisasi merupakan ukuran yang menyebabkan tercapainya tujuan. Maka dapat dikatakan bahwa optimal sama dengan optimasi sangat penting diterapkan dalam suatu sistem untuk mencapai tujuan yang paling baik, paling tinggi, atau paling menguntungkan (Yusgiantoro, 2014, hal. 100-101). Berangkat dari berbagai pendapat tersebut, dapat diambil benang merahnya bahwa, optimalisasi merupakan suatu proses, cara, atau perbuatan untuk menjadikan sesuatu paling baik dan paling tinggi. Menurut Ahmadi dan Hermawan (2013) internet adalah komunikasi jaringan komunikasi global yang menghubungkan seluruh komputer di dunia meskipun berbeda sistem operasi dan mesin. Peran merupakan suatu hubungan individu dengan sistem sosial yang dianalisis melalui konsep status atau peranan.

Warga negara digital sebagai karakteristik kota digital asli mencerminkan suatu ciri khas dari kota digital itu sendiri yang berbeda dengan kota lainnya. Warga negara digital umumnya dapat dikenal sebagai mereka yang menggunakan internet secara teratur dan efektif (Isman \& Gunggoren, 2014). Digital citizenship adalah panduan yang dimediasi untuk perilaku manusia sehingga semua dapat mengambil manfaat dalam masyarakat digital. Tujuan digital citizenship sekarang ini pada dasarnya untuk mendidik, memberdayakan, dan melindungi. Maka jika terjadi hal-hal negatif dalam penggunaan teknologi digital hal ini sudah tidak sesuai lagi dengan tujuan dari digital citizenship itu sendiri. Dalam pandangan Ribble dan Bailey (2011), mendefinisikan digital citizenship terdiri dari konsep tanggung jawab, hak, keamanan. Ketiganya saling membutuhkan satu dengan yang lainnya, sehingga tidak dapat dipisahkan. Ketahanan pribadi siswa menggambarkan kemampuan internal siswa dalam menggalang konsensus dan mengatur sumber daya maupun kemampuannya untuk mengantisipasi faktor eksternal, sehingga bisa mengubah sumber ancaman menjadi peluang. Ketahanan pribadi siswa sangat diperlukan sebagai suatu bentuk keuletan dan ketangguhan dalam menghadapi berbagai macam ancaman baik dari lingkungan internal maupun eksternal. 


\section{Metode}

Penelitian ini menggunakan pendekatan kualitatif karena penggunaan pendekatan kualitatif sangat sesuai dalam penelitian ini, yang pada dasarnya akan mengetahui proses optimalisasi peran internet dalam mewujudkan digital citizenship di Kota Semarang dan mengkaji implikasi dari optimalisasi peran internet terhadap ketahanan pribadi siswa di Kota Semarang. Lokasi penelitian yang dijadikan untuk penelitian ini di SMA Negeri I Semarang dan SMK Negeri 1 Semarang. SMA Negeri 1 Semarang berlokasi di Jalan Taman Menteri Supeno No. 1 Kota Semarang merupakan salah satu bangunan kuno bersejarah di Kota Semarang. Di bangun antara tahun 1936-1938 dan diresmikan tahun 1939. Keberadaan SMA Negeri 1 Semarang tidak lepas dari Sejarah Kota Semarang. "SMANSA Semarang" merupakan julukan yang terkenal pada kalangan mudanya. SMA Negeri 1 Semarang ini merupakan salah satu sekolah menengah atas negeri favorit yang ada di Provinsi Jawa Tengah. Sedangkan SMK Negeri 1 Semarang merupakan sekolah menengah kejuruan teknologi dan industri yang semula bernama Sekolah Teknologi Menengah yang disingkat STM. Sekolah ini merupakan sekolah kejuruan tertua di Provinsi Jawa Tengah dan didirikan dalam urutan kedua setelah STM yang didirikan di Provinsi Daerah Khusus Istimewa Jakarta. Pemilihan kedua sekolah tersebut dijadikan lokasi penelitian, karena dua sekolah itu sebagai sekolah menengah atas dan kejuruan favorit di Kota Semarang yang secara teknologi juga sangat memadai di ibukota Provinsi Jawa Tengah.

Dalam hal ini informan penelitian ditentukan secara purposive sampling hal ini disebabkan karena orientasi penelitian yang dituju guru dan siswa. Guru yang dimaksud yakni guru pendidikan Pancasila dan kewarganegaraan (PPKn) dan guru Teknologi, Informasi, dan Komunikasi (TIK) di SMA Negeri I Semarang dan SMK Negeri I Semarang. Informan tersebut dipilih berdasarkan pertimbangan, bahwa keberadaan sebagai siswa siswi di sekolah tersebut telah lama dan tentunya telah merasakan akses internet lebih lama juga selama ini. Teknik pengumpulan data yang digunakan dalam penelitian ini observasi, wawancara mendalam, focus group discussion (FGD), dan dokumentasi. Setelah pengumpulan data, dilakukan reduksi data dalam penelitian ini yang diperoleh dari hasil observasi, wawancara mendalam, dan FGD. Selanjutnya, dokumentasi kemudian dipilih data-data pokok-pokok dan difokuskan pada hal-hal yang penting, sehingga data menjadi jelas dan sistematis. Data disajikan berupa naratif yang mendeskripsikan tentang informan penelitian, yakni menggambarkan proses optimalisasi peran internet dalam mewujudkan digital citizenship dan implikasi dari optimalisasi peran internet terhadap ketahanan pribadi siswa di Kota Semarang. Tahap terakhir setelah teknik analisis data penarikan simpulan, agar simpulan lebih dapat dipercaya dan kredibel maka dilakukan triangulasi.

\section{Hasil dan Pembahasan}

Internet menjadi kebutuhan penting bagi setiap individu di era digital ini. Kebutuhan tersebut bukan hanya pada kalangan atas yang mempunyai uang dan fasilitas memadai, namun juga kebutuhan tersebut telah terjadi pada kalangan menengah dan bawah. Karena kebutuhan terhadap internet ini bisa menjadikan individu tersebut untuk menguasai dunia. Internet yang digenggam pada tangganya tersebut dapat membuat individu itu mendapatkan segala informasi yang di dunia. Sehingga wajar jika seorang individu membeli kuota internet mahal demi untuk mendapatkan akses internet yang bagus dan lancar. Namun, akses internet di Indonesia belum dapat dinikmati dengan baik oleh semua wilayah. Hal ini disebabkan bukan saja karena wilayah Indonesia yang luas dari Sabang-Merauke, namun juga karena masyarakat Indonesia itu sendiri yang masih kurang dalam memahami penggunaan internet dengan baik.

Melihat kedua realitas tersebut yakni pada sekolah favorit SMA Negeri 1 Semarang dan SMK Negeri 1 Semarang ditemukan data, yang sangat menarik yakni terkait dengan akses digital, 
komunikasi digital, literasi digital, dan perdagangan digital. Sesungguhnya proses optimalisasi peran internet pada kedua wilayah tersebut dilakukan dengan keempat komponen. Prosesnya itu pada dasarnya dilakukan guna membentuk warga negara yang baik dan dalam rangka mewujudkan kewarganegaraan digital di era digital saat ini yang mencakup pengetahuan dan keterampilan untuk menggunakan teknologi digital dengan tepat dan teratur, serta efektif dunia digital (Mossberger et al., 2008; Partnership for 21st Century Skills, 2014). Internet telah memudahkan individu untuk mendapatkan informasi dan mempercepat proses komunikasi dengan yang lainnya. Salah satu yang terkena dampak baik dari mudahnya akses internet tersebut pada kalangan sekolah terutama siswa dan siswi, bahkan gurunya pun turut mendapatkan akses digital tersebut. Sehingga terjadi proses shifting dan transformasi dalam pembelajaran yang dilakukan oleh guru terhadap siswa dan siswi. Sehingga saat ini guru hanya sebagai fasilitator dalam proses belajar mengajar di kelas, hal ini disebabkan karena adanya akses terhadap internet yang mudah dijangkau. Sekiranya akses internet di sekolah kurang cepat dalam pencarian sumber informasi untuk kegiatan akademik, maka siswa dan siswi bisa menggunakan paket kuota internet yang telah dibelinya.

SMA Negeri 1 Semarang sudah menyediakan akses internet yakni dengan adanya koneksi internet nirkabel (wireless) pada sudut-sudut sekolah, dengan kecepatan yang normal dan stabil. Bahkan saat ini fungsinya sudah dioptimalkan sehingga bisa dijangkau pada ruang guru, sekitaran koridor kelas, bahkan setiap siswa dan siswi mempunyai kuota internet pribadinya masing-masing yang telah dibeli. Namun, yang menjadi perhatian siswa tersebut bahwa akses internet masih dalam sudut-sudut tertentu di SMA Negeri 1 Semarang. Sehingga bisa menunjang kebutuhan untuk kegiatan akademik dan non akademik. Dalam hal ini sekolah menyediakan akses internet yang normal dan stabil guna menunjang kebutuhan dari guru, siswa dan siswinya dalam rangka kegiatan akademik dan non akademik.

Proses optimalisasi peran internet di SMA Negeri 1 Semarang untuk kegiatan akademik dilakukan pada saat simulasi kegiatan UNBK, model pembelajaran e-learning, nilai cetak rapor yang menggunakan sistem online, laporan guru dengan menggunakan e-kurikulum, fitur games education, maupun proses kegiatan akademik yang lainnya. Bahwa masih ada guru yang masih menggunakan pembelajaran konvensional, hal ini karena memang materi yang disampaikannya lebih nyaman konvensional dengan model pembelajaran klasikal biasa. Tetapi, dalam evaluasinya guru tersebut yang menggunakan pembelajaran konvensional tetap menggunakan internet. Dalam hal ini keterbukaan pola pikir (mindset) guru untuk melakukan proses pembelajaran berbasis online sangat diperlukan.

Digital literacy menjadi salah satu bagian dari sembilan perilaku guna membentuk digital citizenship. Saat ini orang membaca telah mengalami pergeseran dan perubahan, kalau dulu membaca dengan buku yang harus mencari dan membeli terlebih dahulu bukunya. Namun, saat ini proses tersebut telah mengalami pergeseran dan perubahan. Hanya dengan klik e-book pada google, maka keinginan atas buku dicari bisa muncul dengan segera. Buku dengan terbitan yang lama juga dengan mudah dicari, bahkan ada jutaan file yang dengan mudahnya diunduh pada internet tersebut. Proses pergeseran dan perubahan itu tentunya harus diterapkan pada sekolahsekolah yang ada di Indonesia. Sekolah di Kota Semarang salah satunya telah menerapkan proses literasi ini sebelum memulai pembelajaran di kelas, siswa bukan hanya membaca buku yang ada, namun juga dapat membacanya dari internet. Tentunya dengan pengawasan guru, agar apa yang dibaca sesuai dengan materi pembelajaran.

Literasi sangat menarik dan cocok bagi siswa bahkan guru-guru lainnya sangat mengutamakan pembelajaran dengan menggunakan literasi dan model penggunaan teknologi seperti presentasi dengan menggunakan PowerPoint. Literasi menjadi modal penting komunikasi 
yang memungkinkan individu, masyarakat dan lembaga untuk berinteraksi, dari waktu ke waktu dan di seluruh ruang, karena mereka mengembangkan jaringan hubungan sosial melalui bahasa (Benavot, 2015). Saat ini kurikulum yang dipakai oleh SMK Negeri 1 Semarang merupakan kurikulum 2013, yang mengharuskan siswa aktif sedangkan guru hanya jadi fasilitator. Maka, pembelajaran dengan menggunakan teknologi dilakukan sebagai sebuah kesadaran dari adanya kemajuan teknologi itu sendiri yang berkembang saat ini, dengan derasnya arus globalisasi membawanya. Saat ini literasi telah dikembangkan dan diwajibkan bagi sekolah-sekolah yang ada di Kota Semarang, baik itu menengah atas maupun menengah kejuruan ataupun yang lainnya. Proses literasi dimulai sebelum proses belajar mengajar dimulai. Pukul 07.00 guru memasuki ruang kelas, kemudian menyanyikan lagu Indonesia Raya, kemudian dilanjutkan dengan literasi baru terjadi proses belajar mengajar pada pukul 07.15. Dalam literasi tersebut, bukan hanya siswa yang membaca, guru pun ikut membaca. Guru tidak hanya lepas diri saja atas apa yang siswa baca, melainkan guru juga menanyakan apa yang siswa baca tersebut. Sehingga dalam hal ini memastikan bahwa siswa benar-benar membaca, bukan membaca media sosial lainnya.

Salah satu dari sembilan komponen dalam mewujudkan digital citizenship yakni melalui perdagangan digital. Saat ini proses jual beli bukan lagi dilakukan face to face tetapi melalui penjualan online. Adanya penjualan online ini sesungguhnya menandai dari majunya sebuah peradaban. Peradaban yang maju dengan ditunjang oleh kemajuan dari sebuah teknologi. Teknologi yang ada saat ini telah mampu mengubah kebiasaan dari para produsen dan konsumen. Muncul banyaknya start-up dan e-commerce di Indonesia menjadi tanda bahwa ke depan bukan lagi persaingan pada luasnya tempat, melainkan pada kreativitas, inovasi, dan keunggulan produk, yang ditunjang dengan penjualan dan pembeli melalui sistem online. Ketidakmampuan seseorang dalam memainkan teknologi bisa dipelajari bukan dari bangku sekolah saja, melainkan adanya kemauan dari dalam diri sendiri. Salah satunya siswa dari SMA Negeri 1 Kota Semarang beserta teman-temannya telah membeli barang dari Bandung berupa makanan bakso aci instan, barang yang dibeli tersebut kemudian dijual kembali kepada teman-temannya. Proses ini telah dijalankan sejak di bangku sekolah menengah atas, hal ini dilakukan sebagai bagian dari memanfaatkan media sosial yang menggunakan internet. Internet menjadi hal yang menguntungkan bagi orang yang dapat memanfaatkannya. Namun, dapat menjadi hal yang merugikan manakala hanya untuk halhal yang negatif saja.

Hasil penelitian yang dilakukan oleh Hintz et al. (2017), menjelaskan bahwa bagi kewarganegaraan digital, pemantauan dan pemrosesan aktivitas online dapat menawarkan kemudahan, baik dalam bentuk iklan yang ditargetkan atau konten yang ditujukan kebiasaan dan minat konsumsi. Sementara banyak dari dinamika ini difasilitasi oleh sektor bisnis, memiliki implikasi signifikan bagi hubungan antara warga negara dan negara. Digital citizenship bergantung pada infrastruktur teknis dari internet untuk bertindak dan berinteraksi. Bahkan kewarganegaraan digital membutuhkan perlindungan yang memadai dari hak dasar pengguna internet, yakni kebebasan berekspresi dan privasi. Namun, kebebasan berekspresi harus tahu batasannya jangan sampai membuat dan meresahkan orang lain. Privasi pribadi dan milik orang lain harus terus dijaga jangan sampai data privasi tersebut disalahgunakan untuk hal-hal negatif. Tidak hanya di sektor bisnis saja, temuan penelitian Reichert \& Print (2017) mengungkapkan bahwa Internet (sosial media) merupakan sumber utama dan fasilitator partisipasi kaum muda, baik melalui jalur langsung dan tidak langsung. Bahkan beberapa ahli sepakat bahwa internet (sosial media saat ini) merupakan media partisipasi politik yang efektif (Amnå, 2012; Bennett, 2008; Carpini \& Keeter, 1996; Lee et al., 2013; Norris, 1996; Reichert \& Print, 2017).

Peran yang dimainkan oleh guru dan siswa tersebut merupakan suatu hubungan individu dengan sistem sosial yang dianalisis melalui konsep status atau peranan. Status yang melekat pada 34 
kedudukan suatu sistem sosial dan peranan merupakan perilaku yang diharapkan atau perilaku normatif yang melekat pada status. Sistem sosial individu selalu menduduki suatu tempat (status) dan bertindak (peranan) sesuai dengan norma atau aturan-aturan yang dibuat oleh sistem (Poloma, 2007, hal. 172-173). Peran sebagai digital citizenship berakar pada keprihatinan lama atas proses kemajuan dari yang lainnya. Dalam hal ini, digital citizenship telah memberikan kerangka kerja yang diakui dengan baik untuk mengatasi tantangan perilaku digital yang pantas di seluruh dunia. Oleh karena itu, dalam pendidikan ada beberapa fitur utama untuk membuat para siswa menjadi warga negara digital untuk melihat sasaran digital citizenship abad ke-21.

Proses optimalisasi sebagaimana data yang didapatkan dari lapangan tersebut sesungguhnya telah mempengaruhi ketahanan pribadi siswa dan siswi di sekolah. Siswa dan siswi di sekolah bisa dibilang sebagai kaum muda, secara Undang-Undang telah memenuhi jika usianya 16 tahun. Tentunya ketahanan pribadi siswa dan siswi berbeda dengan generasi sebelumnya baik itu orang tuanya maupun gurunya. Maka dalam hal ini diperlukan ketahanan pribadi siswa dan siswi yang kuat dan tangguh. Ketahanan pribadi sebagai sebuah proses dari ancaman, gangguan, hambatan, dan tantangan baik yang datang dari luar maupun dari dalam. Internet telah membawa implikasi bagi tiap-tiap siswa dan siswi baik itu yang positif maupun yang negatif. Tidak jarang masih ada siswa dan siswi yang menggunakan internet untuk hal-hal yang negatif, jika terdapat razia di sekolah akan dikenakan sanksi dan diberikan point. Namun, mungkin hanya sebagian yang terkena razia dan mendapatkan point hukuman tersebut. Tentunya lebih banyak yang mengakses internet untuk tujuan negatif karena memang ada rasa penasaran dari siswa dan siswi tersebut bahkan tak jarang terkadang muncul sendiri hal-hal negatif tersebut pada internet. Penerapan hukuman digital yang dilakukan oleh sekolah terhadap siswa dan siswi yang mengakses hal negatif, sesungguhnya telah menyadarkan siswa dan siswi dalam menggunakan internet untuk tujuan yang positif.

Penyalahgunaan internet yang dilakukan oleh oknum tertentu secara tidak bertanggungjawab, seperti penyebaran ujaran kebencian, fitnah, hoax, maupun yang lainnya. Seperti diketahui bahwa penggunaan internet terbesar ada pada kalangan generasi muda. Siswa dan siswi sebagai generasi penerus bangsa, yang akan membawa bangsa dan negara ini ke depannya pada suatu era kemajuan. Dalam dunia digital dikenal dengan hukum digital, hukum digital ini ada dan diterapkan karena mencegah agar tidak terjadi penyalahgunaan lagi terhadap akses internet yang negatif bukan untuk yang positif. Hal ini menjadi bagian dari pembentukan digital citizenship. Manakala siswa dan siswi melakukan pelanggaran, seperti membuka situs porno, main game saat pembelajaran, maupun bermain telepon pintar pada saat jam pembelajaran, saat itulah guru akan menyita telepon pintar tersebut. Proses hukuman yang diberikan tersebut mengajarkan kepada siswa dan siswi bahwa menghargai orang lain lebih di utamakan dan menggunakan internet dengan baik dan benar sangatlah dipentingkan bukan malah menggunakan dan menyalahgunakan untuk hal-hal yang negatif. Hukuman tersebut tidaklah dalam bentuk fisik, melainkan untuk menjadi peringatan bersama terutama terhadap siswa dan siswi yang melanggar tersebut. Hukum digital ini dilakukan oleh sekolah guna menjadikan siswa dan siswi dalam rangka mewujudkan warga negara yang baik.

Sejalan dengan penggunaan internet dengan cara yang kurang baik dan tidak dibenarkan, yang dilakukan oleh oknum-oknum yang tidak bertanggungjawab dalam menebarkan kebencian, fitnah, maupun berita bohong. Maka sebagai generasi penerus bangsa, siswa dan siswi perlu dibekali dan di arahkan ke dalam hal-hal yang positif melalui nilai-nilai keindonesiaan. Supaya dalam menggunakan internet dilakukan secara positif dan benar. Sekolah sebagai lembaga formal dan lembaga yang dapat mendidik generasi bangsa dalam memperoleh dan mencerahkan ilmu dan pengetahuannya, sudah sepatutnya memberikan dan mewujudkan digital citizenship pada kalangan siswa dan siswinya. Teknologi, Informasi, dan Komunikasi di SMA Negeri 1 Semarang 
bahwa pemaknaan digital citizenship di sekolahnya dimaknai sebagai digital student atau digital citizen. Digital student ini pada dasarnya telah dikondisikan dalam proses pembelajaran dari mulai guru yang mengajar sampai pada siswa dan siswi itu sendiri. Bahkan proses pembelajaran yang dipakai pun tidak hanya di dalam kelas melainkan bisa dipakai pada luar kelas dengan model pembelajaran tertentu. Model online sangat tepat dalam proses pembelajaran di luar kelas itu. Hal ini pula yang telah dilakukan oleh Kota Semarang dengan jangkauannya yang luas, bisa menjalankan dan menerapkannya. Sedangkan SMA Negeri 1 Semarang masih dalam jangkau dunia pendidikan dalam menerapkannya.

SMA Negeri 1 Semarang mengajarkan siswa dan siswi nya cara berinternet yang positif dan sehat, termasuk dengan mendatangkan alumni-alumni SMA Negeri 1 Semarang sendiri. Internet positif dan sehat tersebut kemudian diaplikasikan dalam bentuk aplikasi di SMA Negeri 1 Semarang, supaya tertib, damai, dan aman. Melihat hal tersebut dilakukan, sesungguhnya bagian dari membentuk digital citizenship. Pada lima sub indikator di atas yang diteliti, dapat diklasifikasikan ke dalam dua aspek yang melihat dari aspek pendidikan dan aspek ekonomi. Untuk lebih jelasnya dapat diterangkan dalam tabel berikut ini:

Tabel 1

Klasifikasi Perilaku yang Membentuk Digital Citizenship

\begin{tabular}{|c|c|c|}
\hline $\begin{array}{l}\text { Perilaku yang Membentuk } \\
\text { Digital Citizenship }\end{array}$ & Aspek Pendidikan & Aspek Ekonomi \\
\hline Akses Digital & $\begin{array}{l}\text { Tersedianya akses internet di } \\
\text { lingkungan sekolah untuk } \\
\text { kegiatan akademik }\end{array}$ & $\begin{array}{l}\text { Tersedianya internet di tempat area } \\
\text { sekolah untuk kebutuhan penjualan } \\
\text { dan pembelian }\end{array}$ \\
\hline Digital Literacy & $\begin{array}{l}\text { Proses digital literacy } \\
\text { diterapkan sebelum proses } \\
\text { pembelajaran dimulai pada } \\
\text { kedua sekolah yang dilakukan } \\
\text { penelitian }\end{array}$ & $\begin{array}{l}\text { Dalam hal ini siswa dan siswi } \\
\text { menggunakan internet, untuk } \\
\text { membaca berita terhadap kenaikan } \\
\text { produk yang akan dijualnya }\end{array}$ \\
\hline Perdagangan Digital & $\begin{array}{l}\text { Informan banyak yang } \\
\text { menjalankan proses penjualan } \\
\text { dan pembelian bahkan } \\
\text { menjual barang melalui } \\
\text { internet yang tersedia }\end{array}$ & $\begin{array}{l}\text { Terjadinya proses transformasi dan } \\
\text { pergeseran terhadap penjualan dan } \\
\text { pembelian, jika dulu face to face, } \\
\text { saat ini siswa, siswi, dan guru lebih } \\
\text { banyak yang melalui media sosial }\end{array}$ \\
\hline Hukum Digital & $\begin{array}{l}\text { Masih terjadinya akses } \\
\text { terhadap hal negatif, hal ini } \\
\text { ditemukan ketika razia di } \\
\text { sekolah }\end{array}$ & $\begin{array}{l}\text { Adanya kecurigaan dari siswa dan } \\
\text { siswi terhadap pembelian produk } \\
\text { yang dikirim keluar kota tanpa } \\
\text { pembayaran terlebih dahulu }\end{array}$ \\
\hline $\begin{array}{l}\text { Mewujudkan } \\
\text { Digital Citizenship }\end{array}$ & $\begin{array}{l}\text { Mewujudkannya dengan } \\
\text { proses kegiatan akademik dan } \\
\text { pembelajaran yang diterapkan } \\
\text { secara langsung }\end{array}$ & $\begin{array}{l}\text { Mewujudkannya melalui transaksi } \\
\text { penjualan dan pembelian melalui } \\
\text { media sosial terhadap produk yang } \\
\text { dihasilkan }\end{array}$ \\
\hline
\end{tabular}

Sumber: Data diolah oleh peneliti, 2018.

Penjelasan terkait dengan implikasi dari optimalisasi peran internet terhadap ketahanan pribadi siswa di Kota Semarang yang terdiri dari sub indikator hukum digital dan mewujudkan digital citizenship. Sesungguhnya sangatlah sesuai dengan penelitian terkait digital citizenship pernah dilakukan Richard (2010), yang menyoroti pentingnya pertimbangan lembaga pendidikan 
tentang penggunaan alat-alat ini dalam pengaturan sekolah untuk mempromosikan kewarganegaraan pada saat siswa sudah terkena platform komunikasi online yang kuat. Bahkan harus dapat memainkan peran pentingnya dalam mempromosikan demokrasi dan keadilan sosial diperiksa. Guru memainkan dari panduan yang ada ketika siswa mengalami kemungkinan komunikasi dalam media ini. Setelah siswa memiliki kesempatan untuk menjadi akrab dengan antarmuka dan struktur organisasi, guru dapat memulai penataan kegiatan yang dimulai pada jaringan pribadi.

Dalam pendidikan ada beberapa fitur utama untuk membuat para siswa menjadi digital citizenship untuk melihat sasaran digital citizenship abad ke-21. Digital citizenship umumnya diindentifikasi sebagai mereka yang menggunakan internet secara teratur dan efektif (Isman \& Gunggoren, 2014). Digital citizenship merupakan panduan untuk dimediasi dalam perilaku manusia sehingga semua dapat mengambil manfaat dalam masyarakat digital. Tujuan dari digital citizenship sekarang ini pada dasarnya untuk mendidik, memberdayakan, dan melindungi. Bahkan Ribble dan Bailey (2011) yang telah mendefinisikan digital citizenship terdiri dari konsep tanggung jawab, hak, keamanan.

Ketahanan pribadi siswa menggambarkan kemampuan internal siswa dalam menggalang konsensus dan mengatur sumber daya maupun kemampuannya untuk mengantisipasi faktor eksternal, sehingga bisa mengubah sumber ancaman menjadi peluang. Hal ini dapat dianalogikan bahwa ketahanan pribadi siswa, dalam hasil penelitian tersebut sangat erat kaitannya antara pola perilaku siswa dalam rangka memilih informasi yang ada dan beredar melalui media sosial yang didukung dengan akses internet. Ketahanan pribadi siswa dalam hal ini akan sangat rawan manakala tidak diajarkan dengan cara penggunaan internet positif dan sehat. Ketahanan pribadi siswa perlu diarahkan dan dipupuk untuk menuju hal-hal yang positif dalam penggunaan internet, sehingga dapat memanfaatkan untuk kemajuan dirinya, masyarakat, bangsa, dan negara. Menghadapi era yang serba berbasis digital ini sesungguhnya siswa siswi baik di SMA Negeri 1 maupun SMK Negeri 1 Kota Semarang bahkan di Indonesia secara keseluruhan sangat memerlukan suatu proses pertahanan diri yang sangat kuat untuk menghadapi ancaman yang datang secara tak terduga baik dari faktor internal maupun eksternal.

\section{Simpulan}

Internet yang seharusnya digunakan untuk kebutuhan yang positif dan sehat namun, seiring dengan kemajuan teknologi yang tanpa batas tersebut kemudian internet disalahgunakan untuk hal yang negatif. Proses optimalisasi peran internet dalam mewujudkan digital citizenship di SMA Negeri 1 Semarang, SMK Negeri 1 Semarang, dan kampung UKM digital dilakukan dengan mengoptimalkan akses digital, literasi digital, dan perdagangan digital. Sedangkan implikasi dari optimalisasi peran internet terhadap ketahanan pribadi siswa pada SMA Negeri 1 Semarang dan SMK Negeri 1 Semarang itu dengan adanya hukum digital dan mewujudkan digital citizenship. Sembilan kriteria dalam mewujudkan digital citizenship sesungguhnya telah terpenuhi, dalam hal ini masih harus ada perbaikan untuk mengoptimalkannya. Terutama pada aspek pengawasan terhadap penggunaan internet yang dilakukan oleh siswa. Perbaikan terhadap penggunaan dan optimalisasi internet masih banyak kendalanya. Kendala tersebut disebabkan selain dari keluarga, masih kurangnya pengawasan dari guru terhadap siswa, karena tidak selama 24 jam penuh guru bisa mengawasi siswa. Peran semua pihak dalam hal ini sangat diperlukan guna mewujudkan digital citizenship. Digital citizenship pada dasarnya untuk mendidik, memberdayakan, dan melindungi. Dengan mengoptimalkan internet ini, sesungguhnya dapat membawa pada kemajuan peradaban bangsa dan negara. 


\section{Ucapan Terima Kasih}

Terima kasih yang tak terhingga diucapkan kepada Program Studi Ketahanan Nasional dan Dekanat Sekolah Pascasarjana, Universitas Gadjah Mada, yang telah memberikan dukungan secara finansial berupa dana hibah bersaing pada tahun 2018. Selanjutnya tidak lupa kepada siswa, siswi dan guru SMA Negeri 1 dan SMK Negeri 1 Kota Semarang, yang dengan penuh keramahannya telah bersedia meluangkan waktunya untuk dilakukan wawancara.

\section{Referensi}

Ahmadi, \& Hermawan. (2013). E-business \& e-commerce. Andi.

Amnå, E. (2012). How is civic engagement developed over time? Emerging answers from a multidisciplinary field. Journal of adolescence, 35(3), 611-627.

Benavot, A. (2015). Literacy in the 21st century: towards a dynamic nexus of social relations. International Review of Education, 61(3), 273-294. https://doi.org/10.1007/s11159-015-9463-3

Bennett, W. L. (2008). Changing citizenship in the digital age. In W. L. Bennett (Ed.), Civic life online: Learning how digital media can engage youth: Vol. (hal. 1-24). The MIT Press. https://doi.org/10.1162/dmal.9780262524827.001

Carpini, M. X. D., \& Keeter, S. (1996). What Americans know about politics and why it matters. Yale University Press.

Friedman, L. T. (1999). Judgment not included. New Yorks Times.

Hintz, A., Dencik, L., \& Wahl-Jorgensen, K. (2017). Digital citizenship and surveillance society. International Journal of Communication, 11, 731-739. https://doi.org/10.1073/pnas.1706286114

Isman, A., \& Gunggoren, O. C. (2014). Digital citizenship. TOJET: The Turkish Onlline Journal od Education Technology, 13(1), 73-77.

Lee, N.-J., Shah, D. V., \& McLeod, J. M. (2013). Processes of political socialization: A communication mediation approach to youth civics engagement. Communication Research, 40(5), 669-697. https://doi.org/10.1177/0093650212436712

Martono, N. (2014). Sosiologi suatu perubahan. Raja Grafindo Persada.

Mossberger, K., Tolbert, C. J., \& McNeal, R. S. (2008). Digital citizenship. The internet, society, and participation. The MIT Press.

Norris, P. (1996). Does television erode social capital? A reply to Putnam. PS - Political Science and Politics, 29(3), 474-480. https://doi.org/10.1017/S104909650004511X

Partnership for 21st Century Skills. (2014). Reimagining citizenship for the 21st century: a call to action for policymakers and educators. http://www.p21.org/storage/documents/Reimagining_Citizenship_for_21st_Century_webversion. pdf

Poloma, M. M. (2007). Sosiologi kontemporer. Raja Grafindo Persada.

Poushter, J., Bishop, C., \& Chwe, H. (2018). Social media use continues to rise in developing countries but plateaus across developed ones. In Pew Research Center: Vol. June.

Reichert, F., \& Print, M. (2017). Mediated and moderated effects of political communication on civic participation. Information, Communication \& Society, 20(8), 1162-1184.

Ribble, M., \& Bailey, G. (2011). Digital citizenship in schools. : International Society for Technology in Education (ISTE). https://doi.org/10.1111/j.1467-8535.2012.01378_9.x

Richards, R. (2010). Digital citizenship and web 2.0 tools. MERLOT Journal of Online Learning and Teaching, 6(2), 516-522.

Scobey, D. (2001). The specter of citizenship. Citizenship Studies, 5(1), 11-26. https://doi.org/10.1080/13621020020025169 
Smith, A. (2017, Januari 12). Record shares of Americans have smartphones, home broadband / Pew Research Center. https://www.pewresearch.org/fact-tank/2017/01/12/evolution-of-technology/

Wahidin, D. (2018). Peran internet dalam mewujudkan digital citizenship (Studi di kampung cyber kota Yogyakarta). Jurnal PPKn, 6(1), 1200.

Xu, S., Yang, H. H., MacLeod, J., \& Zhu, S. (2019). Social media competence and digital citizenship among college students. Convergence, 25(4), 735-752. https://doi.org/10.1177/1354856517751390

Yudhianto. (2017). 132 Juta Pengguna Internet Indonesia, 40\% Penggila Medsos. https://inet.detik.com/cyberlife/d-3659956/132-juta-pengguna-internet-indonesia-40-penggilamedsos

Yusgiantoro, P. (2014). Ekonomi pertahanan. Gramedia Pustaka Utama. 